\title{
The role of small farms in ensuring food security in Russia
}

\author{
Ekaterina Sapozhnikova ${ }^{1 *}$ and Olesya Ryazanova ${ }^{1}$ \\ ${ }^{1}$ Vyatka State University, Moskovskaya str., 36, Kirov, 610000, Russia
}

\begin{abstract}
Food security is the most important area of national security. The market economy has led to the formation of new categories of agricultural producers. Country farms and personal subsidiary farms belong to the group of small farms. Modern approaches to determining the state of food security are discussed in the article. Indicators for assessing the role of small farms in food security are given. The method of calculating indicators is based on the provisions of the Food Security Doctrine and modern scientific concepts. Food independence analysis conducted. Indicators of independence from external supplies are defined for 2000-2017. The level of satisfaction of needs due to production in small farms is calculated. The growing role of peasant farms is determined in the food self-sufficiency of Russia. The direction of development of small farms investigated. Government support measures identified. The organizational and economic conditions for the development of small farms are presented.
\end{abstract}

\section{Introduction}

Food security is a component of national security. Moreover, food security is a basis of ensuring health, physical activity, longevity and quality life of the country's population. Small farms play an essential role in the solution of the designated tasks. Small farms are presented by country farms and personal subsidiary farms. These categories of agricultural producers have appeared in a process of formation of market rural economics in Russia.

Personal subsidiary farms are a form of not business activity of citizens on production and processing of agricultural production. This economy is conducted by the citizen and members of his family for satisfaction of personal needs on the land plot. The difference between country farms lies in the form of organization of business activities. Small farms function within restrictions of the sizes and annual total revenue. Country farm is an independent business, is managed by its owner or part owners and has a small market share [1]. Farmers may be specialized in agriculture, with farm income and production providing a substantial share of their income [2]. However, many farms derive some proportion of total income by relying on off-farm sources [3].

History of small farms in Russia's agro-industrial complex has shown their considerable degree to stability during crisis processes in economy. Many scientists explain it with the fact that small farms possess high degree of adaptability to changing to conditions of the market

\footnotetext{
* Corresponding author: gasmin.87@mail.ru
} 
environment. It is necessary to note the influence of the small size of the functionalization of peasant farms and personal subsidiary farms. This allows them to quickly adapt to changing conditions. These statements are objective under certain conditions. These conditions are well-established integration links with agricultural enterprises, the availability of sufficient fixed and current assets. This situation was observed in the early nineties in Russia. Small farms had the sufficient resource potential, the developed directions of interaction with the agricultural enterprises. These conditions have been created in the period of planned economy in Russia. Country and farmer and personal subsidiary farms have taken the predominating positions in production of potatoes, vegetables of the open ground, some types of livestock production during this period. The number of personal subsidiary farms amounted to 18718.6 thousand according to the results of the All-Russian Agricultural Census. The number of country farms was 174765 .

The food supply of the population, the provision of employment and incomes of the rural population, the formation of the middle class in the village, the village-forming mission, the preservation of the rural way of life and traditional culture, social control over the territories, assistance in filling the local budgets of rural areas are the main functions of small farms. Small farms develop an enterprise initiative in the conditions of market economy. The main function of small farms is the food supply of the population. The modern policy of the agrarian sector is directed to support of domestic agricultural manufacturers.

\section{Materials and Methods}

The research is based on materials of the Federal State Statistics Service and the Ministry of Agriculture of the RF with the methods of complex economic analysis. The object of scientific research is the criteria and conditions for achieving food security in Russia at the present stage. The subject of the study is the participation of small forms in ensuring food security. A methodological basis for the research included indicators of the level of food independence, applied by Russian state bodies according to the Doctrine of food security, and indicators and concepts of determination of this indicator and system of economic security of agro-industrial complex on the whole.

The level of food independence was determined by the following formula:

$$
I_{f i}=\left(S_{b}+Q-S_{e}\right) / C_{p}
$$

where $I_{f i}$, - level of food independence; $S_{b}$, - reserves at the beginning of the year; $S_{e}$, - reserves at the end of the year; $Q$ - production volume, and $C_{p}$ - volume of private and production consumption within the country.

The coefficient determines the ratio of the volumes of domestic production of agricultural products with the volume of domestic needs. Food independence is achieved if the volume of production (including reserves) is greater than the volume of consumption [4].

Indicator of food independence from external supplies is calculated by the following formula:

$$
I_{e s}=(1-\operatorname{Im} /(Q-E x)) \times 100 \%
$$

where $I_{f d}$ - level of food independence from external supplies, Im - volume of import, and Ex is the volume of export.

The level of need satisfaction due to production in small farms in the Russian Federation was determined by the following formula:

$$
I_{n s s f}=Q_{s f} / C_{p} \times 100 \%
$$


where $I_{n s}$ - level of need satisfaction due to production in small farms; $Q_{s f}$ - volume of agricultural production in small farms.

The level of need satisfaction due to production in personal subsidiary farms in the Russian Federation was determined by the following formula:

$$
I_{n s p f}=Q_{p s f} / C_{p} \times 100 \%
$$

where $I_{n s}$ - level of need satisfaction due to production in personal subsidiary farms; $Q_{p s f}$ volume of agricultural production in personal subsidiary farms.

The level of need satisfaction due to production in country farms in the Russian Federation was determined by the following formula:

$$
I_{n s c f}=Q_{c f} / C_{p} \times 100 \%
$$

where $I_{n s}$ - level of need satisfaction due to production in country farms; $Q_{c f}$ - volume of agricultural production in country farms.

\section{Results}

Sustainable development of domestic production of food and raw materials is one of the main tasks of ensuring food security in Russia. The volume of agricultural production shows a steady upward trend over the past 8 years. Growth in agricultural production amounted to $41.7 \%$ in 2017 compared to 2010 . However, this trend is not typical for all categories of producers. This figure was $68.6 \%$ for enterprises, $140 \%$ - for country farms. Personal subsidiary farms could not increase production. Moreover, production has decreased by $8.5 \%$ over the past 4 years.

The identified problem is serious. This is due to the fact that personal subsidiary farms produced the bulk of production traditionally. The situation begins to change dramatically in the last 7 years. Personal subsidiary farms were the main producers of crop and livestock products in 2000-2010 (table 1). Socio-economic problems led to the loss of the leading positions of this category of producers. In addition, the scale of operation of agricultural enterprises increased significantly. The positions of peasant farms have also improved. This category of producers produces almost one fifth of crop production in Russia today.

Table 1. The share of small farms in production of agriculture in the Russian Federation in 2000$2017, \%$.

\begin{tabular}{|l|c|c|c|c|c|}
\hline \multicolumn{1}{|c|}{ Indicator } & $\mathbf{2 0 0 0}$ & $\mathbf{2 0 0 5}$ & $\mathbf{2 0 1 0}$ & $\mathbf{2 0 1 5}$ & $\mathbf{2 0 1 7}$ \\
\hline $\begin{array}{l}\text { Agricultural } \\
\text { products, including }\end{array}$ & 54.8 & 55.4 & 55.6 & 48.6 & 47.3 \\
$-\quad \begin{array}{l}\text { personal } \\
\text { subsidiary farms }\end{array}$ & 51.6 & 49.3 & 48.3 & 37.4 & 34.6 \\
farms country & 3.2 & 6.1 & 7.2 & 11.1 & 12.7 \\
\hline $\begin{array}{l}\text { Crop products, } \\
\text { including }\end{array}$ & 52.1 & 56.0 & 59.2 & 53.2 & 52.6 \\
$\begin{array}{l}\text { subsidiary farms } \\
-\quad \text { country } \\
\text { farms }\end{array}$ & 47.8 & 46.5 & 48.0 & 36.7 & 33.6 \\
\hline $\begin{array}{l}\text { Livestock products, } \\
\text { including }\end{array}$ & 57.8 & 54.8 & 52.4 & 43.1 & 41.2 \\
\hline
\end{tabular}




\begin{tabular}{|l|c|c|c|c|c|}
$-\quad \begin{array}{l}\text { personal } \\
\text { subsidiary farms }\end{array}$ & 56.0 & 52.0 & 48.5 & 38.3 & 35.8 \\
\hline$-\quad$ country & 1.8 & 2.8 & 3.9 & 4.8 & 5.4 \\
\hline
\end{tabular}

The importance of small farms in ensuring food security of Russia remains high. Country farms are focused on commodity production. Personal subsidiary farms differ significantly in their objectives. Some farms are exclusively subsidiary nature of production. The main goal is to provide the family with food. Another part of the farms produces products for sale. These farms are characterized by large scale production.

A feature of personal subsidiary farms is their high degree of stability in a market economy. Personal farms occupy less than $5 \%$ of the acreage in Russia. At the same time, they produce more than a third of the gross agricultural output.

The importance of private farms has increased in providing the population with milk, dairy products and cattle meat during the years of the market economy. The number of cattle decreased by 5.2 times in agricultural enterprises over the years of reform. The share of cattle of these farms was $42.2 \%$ in 2017.

The share of cattle in personal subsidiary farms increased during the period of agrarian reform - from $17.3 \%$ in 1990 to $42.2 \%$ in 2017 . The share of the livestock of cows was over $47 \%$ in some years. The number of pigs in personal subsidiary farms has halved over the past two years. This is due to the construction of large pig complexes and an increase in animals in agricultural enterprises. 19.9 million heads of pigs were kept in agricultural enterprises in 2017. This is 1.8 times more than in 2010 . The number of pigs in personal subsidiary farms decreases annually. This is due to several reasons:

- reduction of the rural population (by 1.1 million people as compared with 1990),

- decrease in the number of farms containing animals (their number has increased by $8 \%$ in the last 10 years),

- significant increase in prices for feed. This influenced the increase in the cost of pork production and reduced the interest of rural residents to grow and fatten pigs. In addition, farms are experiencing difficulties with the sale of products. The state provides insufficient support. These reasons had a negative impact on the development of pig breeding in private farms.

The reduction in livestock has affected the decline in meat production in private farms. The share of farms was 58\% in meat production in Russia in 2010 (table 2). This figure is less than a fifth of the production at present. More than half of the milk production was made in personal subsidiary farms of the population in 2010. The reduction in the number of cows has led to a decrease in milk production by 3.4 million tons over the past 7 years. However, positive changes are noted. For example, milk yield increased by more than $900 \mathrm{~kg}$ per cow over the years of reforms.

Table 2. The share and volume of agricultural production in small farms in the Russian Federation in 2000-2017.

\begin{tabular}{|c|c|c|c|c|c|c|}
\hline \multicolumn{2}{|c|}{ Indicator } & 2000 & 2005 & 2010 & 2015 & 2017 \\
\hline \multicolumn{7}{|c|}{ Personal subsidiary farms } \\
\hline \multirow{2}{*}{ Potatoes } & $\mathrm{mln}$ tons & 26.9 & 25.0 & 17.8 & 26.1 & 22.8 \\
\hline & $\%$ & 91.2 & 88.8 & 84.0 & 77.6 & 77.2 \\
\hline \multirow{2}{*}{ Vegetables } & mln tons & 8.1 & 8.4 & 8.7 & 10.8 & 10.3 \\
\hline & $\%$ & 74.7 & 74.4 & 71.5 & 67.0 & 62.9 \\
\hline \multirow{2}{*}{ Meat } & $\mathrm{mln}$ tons & 2.5 & 2.6 & 2.6 & 2.2 & 2.1 \\
\hline & $\%$ & 58.0 & 51.4 & 36.5 & 22.5 & 19.7 \\
\hline Milk & $\mathrm{mln}$ tons & 16.4 & 16.1 & 16.0 & 14.1 & 13.1 \\
\hline
\end{tabular}




\begin{tabular}{|c|c|c|c|c|c|c|}
\hline & $\%$ & 50.9 & 51.8 & 50.4 & 45.6 & 42.1 \\
\hline \multirow{2}{*}{ Eggs } & $\begin{array}{l}\text { billion } \\
\text { pieces }\end{array}$ & 9.8 & 9.5 & 9.0 & 8.8 & 8.5 \\
\hline & $\%$ & 28.8 & 25.7 & 22.1 & 20.6 & 18.9 \\
\hline \multicolumn{7}{|c|}{ Country farms } \\
\hline \multirow[t]{2}{*}{ Potatoes } & $\begin{array}{l}\text { thousand } \\
\text { tons }\end{array}$ & 375 & 802 & 1175 & 2895 & 2510 \\
\hline & $\%$ & 1.3 & 2.8 & 5.5 & 8.6 & 8.5 \\
\hline \multirow[t]{2}{*}{ Vegetables } & $\begin{array}{l}\text { thousand } \\
\text { tons }\end{array}$ & 263 & 781 & 1388 & 2427 & 5296 \\
\hline & $\%$ & 2.4 & 6.9 & 11.4 & 15.1 & 15.9 \\
\hline \multirow[t]{2}{*}{ Meat } & $\begin{array}{c}\text { thousand } \\
\text { tons }\end{array}$ & 80 & 119 & 210 & 279 & 301 \\
\hline & $\%$ & 1.8 & 2.4 & 2.9 & 2.9 & 2.9 \\
\hline \multirow[t]{2}{*}{ Milk } & $\begin{array}{l}\text { thousand } \\
\text { tons }\end{array}$ & 568 & 981 & 1484 & 2035 & 2391 \\
\hline & $\%$ & 1.8 & 3.1 & 4.7 & 6.6 & 7.7 \\
\hline \multirow{2}{*}{ Eggs } & mln pieces & 141 & 260 & 303 & 369 & 465 \\
\hline & $\%$ & 0.4 & 0.7 & 0.8 & 0.9 & 1.1 \\
\hline
\end{tabular}

The production of meat and poultry eggs was significantly reduced in the farms of the population. This is due to the reduction in the number of birds, infectious diseases, and the increase in prices for feed. Significantly increased costs. The efficiency of production has decreased. The population has lost interest in producing these types of products. However, the importance of personal subsidiary farms is great in solving Russia's food problem.

Subsidiary farms are of great importance in providing the population of the country with potatoes and vegetables. Potatoes and vegetables occupy the largest share in the structure of sown areas of households.

Personal subsidiary farms are the main producers of this crop production. The share of potatoes in the volume of state production was $77.2 \%$ (in previous periods it exceeded $80 \%$ ). Vegetable production has increased 1.3 times in the last 17 years. These figures indicate that personal subsidiary farms occupy one of the key positions in ensuring food security of Russia.

Personal subsidiary farms are the main producers of agricultural products in certain regions of Russia. For example, these farms produce more than $80 \%$ of meat in the Chechen Republic and the Republic of Dagestan, more than $80 \%$ of milk in Astrakhan, Vologda and Rostov regions. This confirms the great importance of farms in providing the population with food. These products are of high quality and always in great demand. The material well-being of the population is growing due to the sale of surplus agricultural products. Income from personal subsidiary farms accounts for at least $20-30 \%$ in the budget structure of many rural families.

Special attention should be paid to the importance of country farms in ensuring the Russia's food security. This category of manufacturers is the most promising. The dynamic development of country farms was accompanied by structural shifts in the distribution of agricultural production by categories of farms. Farms significantly increased their crops and the production of potatoes and vegetables. The production of potatoes increased 6.7 times, vegetables - 20.1 times over the past 17 years.

Country farms are the only category of producers that increased the livestock of farm animals during the period of agrarian transformations. The number of cattle has increased 1.7 times, sheep and goats - 1.5 times in 2010-2017. The exception was the content of pigs. The livestock of these animals has decreased by 2 times. This was due to the agrarian policy aimed at supporting, reconstructing and creating large pig farms in enterprises. The 
development of the meat industry, which plays a significant role in the diet of the population, is a strategically important task in achieving the country's food security [5]. The presented data allow to conclude that the role of small farms in ensuring Russia's food security is increasing. The potential of farms is quite high.

The national approach to evaluation of food security is focused on the problem of food independence, which - under the conditions of Russia's membership in the WTO and orientation at import substitution - is a priority. Food security is determined by the level of self-satisfaction of population's needs for food products by means of own production of the main types of agricultural products, raw materials, and food [6].

An analysis of Russia's food independence showed that independence has been achieved for most food products at present. Moreover, the level of independence continues to grow. Food independence in crop production significantly exceeds the thresholds established by the Doctrine (table 3).

Table 3. Food independence of Russia in 2000-2017, \%.

\begin{tabular}{|l|c|c|c|c|c|c|}
\hline \multicolumn{1}{|c|}{$\begin{array}{c}\text { Food } \\
\text { products }\end{array}$} & Normative & 2000 & 2005 & 2010 & 2015 & 2017 \\
\hline Grain & $>95$ & 95.9 & 117.5 & 122.4 & 144.8 & 156.9 \\
\hline Potato & $>95$ & 101.2 & 102.0 & 101.0 & 105.4 & 101.9 \\
\hline $\begin{array}{l}\text { Meat and } \\
\text { meat } \\
\text { products }\end{array}$ & $>85$ & 69.1 & 62.0 & 72.4 & 88.9 & 93.4 \\
\hline $\begin{array}{l}\text { Milk and } \\
\text { dairy } \\
\text { products }\end{array}$ & $>90$ & 91.3 & 82.3 & 80.6 & 81.0 & 83.8 \\
\hline
\end{tabular}

The ambiguous situation is with respect to livestock products. The growth in the production of meat and meat products led to the achievement of standards in 2015-2017. A reduction in cattle numbers has led to a decrease in milk production. Food independence for this product is below the standard value in 2005-2017.

Analysis of the state of Russia's food security should include an assessment of the volume of exported and imported agricultural products. Special attention is paid to the realization of the export potential of the agro-industrial complex of the country in the context of globalization of the world economy. The expansion of export potential contributes to the growth of rural employment, the creation of new modern agricultural enterprises, the transition to the production of high-quality competitive products, the preservation of foreign exchange earnings within the state, the improvement of the trade balance, and food security based on import substitution. However, the volume of food imports significantly exceeded exports throughout the study period. Thus, the import of food and agricultural raw materials exceeded their exports by 4.6 times in 2010 . This ratio decreased significantly. This figure is 1.4 times at present. At the same time, dependence on external supplies is observed in many types of agricultural products (Table 4).

Table 4. Indicators of food independence from external supplies in Russia in 2000-2017.

\begin{tabular}{|l|c|c|c|c|c|}
\hline \multicolumn{7}{|c|}{ Indicator } & $\mathbf{2 0 0 0}$ & $\mathbf{2 0 0 5}$ & $\mathbf{2 0 1 0}$ & $\mathbf{2 0 1 5}$ & $\mathbf{2 0 1 7}$ \\
\hline \multicolumn{7}{|c|}{ Production, mln tons } \\
\hline Grain & 65.4 & 77.8 & 61.0 & 104.8 & 135.4 \\
\hline Potato & 29.5 & 28.1 & 21.1 & 33.6 & 21.8 \\
\hline Vegetables and gourds & 11.4 & 12.1 & 13.3 & 17.7 & 15.4 \\
\hline Meat and meat products & 4.4 & 5.0 & 7.2 & 9.6 & 10.3 \\
\hline Milk and dairy products & 32.3 & 30.8 & 31.8 & 30.8 & 30.2 \\
\hline
\end{tabular}




\begin{tabular}{|l|c|c|c|c|c|}
\hline $\begin{array}{l}\text { Eggs and egg products } \\
\text { (mln pieces) }\end{array}$ & 34085 & 37091 & 40600 & 42570 & 44790 \\
\hline \multicolumn{5}{|c|}{ Export, mln tons } \\
\hline Grain & 1.3 & 12.2 & 13.9 & 30.7 & 43.3 \\
\hline Potato & 0.03 & 0.03 & 0.09 & 0.21 & 0.25 \\
\hline Vegetables and gourds & 0.2 & 0.9 & 0.5 & 1.1 & 0.4 \\
\hline Meat and meat products & 0.04 & 0.07 & 0.1 & 0.1 & 0.3 \\
\hline Milk and dairy products & 0.5 & 0.5 & 0.5 & 0.6 & 0.6 \\
\hline $\begin{array}{l}\text { Eggs and egg products } \\
\text { (mln pieces) }\end{array}$ & 326 & 197 & 244 & 354 & 720 \\
\hline \multicolumn{7}{|l|}{ Import, mln tons } \\
\hline Grain & 4.7 & 1.5 & 0.4 & 0.8 & 0.7 \\
\hline Potato & 0.6 & 0.5 & 1.1 & 0.9 & 1.5 \\
\hline Vegetables and gourds & 2.2 & 3.5 & 3.2 & 2.6 & 2.7 \\
\hline Meat and meat products & 2.1 & 3.1 & 2.9 & 1.4 & 1.1 \\
\hline Milk and dairy products & 4.7 & 7.1 & 8.2 & 7.9 & 7.1 \\
\hline $\begin{array}{l}\text { Eggs and egg products } \\
\text { (mln pieces) }\end{array}$ & 1168 & 882 & 901 & 1236 & 1225 \\
\hline \multicolumn{7}{|l|}{ Level of independence from external supplies, \% } \\
\hline Grain & 92.7 & 97.7 & 99.2 & 98.9 & 98.9 \\
\hline Potato & 98 & 98.2 & 94.8 & 97.3 & 94.9 \\
\hline Vegetables and gourds & 80.4 & 68.7 & 75 & 84.3 & 75.9 \\
\hline Meat and meat products & 51.8 & 37.1 & 59.2 & 85.3 & 74.8 \\
\hline Milk and dairy products & 85.2 & 76.6 & 73.8 & 73.8 & 77.7 \\
\hline Eggs and egg products & 96.5 & 97.6 & 97.8 & 97.1 & 96.4 \\
\hline
\end{tabular}

The problem of dependence on imports manifests itself in the market of livestock products. Imports of fresh and frozen meat (poultry meat bases) amounted to 643 thousand tons in 2017 . This is $24 \%$ more than in 2010 . However, the total volume of import of meat products is decreasing. Export volumes are growing. But the ratio of these indicators does not cover the high dependence on external supplies. Significant imports are traditional in the dairy market. First of all, this situation relates to the supply of butter and milk fat. They are among the most consumed by the population in Russia. Exports of these products have increased annually by $2 \%$ in the last 18 years. Milk production lags behind the needs of the population significantly in Russia.

Plant production is least dependent on external supplies. Russia is one of the largest producers and exporters of grain in the world. Grain export volumes increased 33.3 times in 2017 compared to 2000. Russia is a major player in the global wheat market [7]. Russia ranks third in the world in potato production. However, the volume of potato production is reduced annually. While imports of these products are growing. The problem consists in the following: the profitability of import operations is higher in comparison with purchases from domestic producers for intermediary structures. Purchase prices from importers are 2 times lower than from domestic manufacturers. The provision of vegetable products is dependent on external supply to the greatest extent. Import exceeds exports by 6.8 times.

High import dependence reduces food security significantly. This situation infringes the national interests of the country significantly. Growth in food imports leads to a weakening of Russia's role in the global economy, trade and politics. Importation of substandard products is a threat to food security as well. For example, low quality products are imported from economically developed countries. This is due to the fact that there is no demand for these products on the market. Dependence on external supplies should be no more than $90 \%$. However, the contribution of different categories of agricultural producers is different. 
Therefore, an assessment of the value of small businesses in ensuring independence from external supplies is necessary.

The level of need satisfaction by crop production is high (table 5). Production and personal consumption of potatoes is fully ensured by production in small farms at the present time. The main producers are personal subsidiary farms. However, the increase in production in country farms contributes to the strengthening of their role in the food self-sufficiency of potatoes in Russia.

Small farms have made a significant contribution to the consumption of vegetables and melons. Personal subsidiary farms produce the bulk of this crop production. But the volume of production is reduced in personal subsidiary farms. Country farms have increased vegetable production by 20 times over the past 18 years. The level of need satisfaction at the expense of production in peasant farms increased from 2 to $30.3 \%$.

Table 5. The level of need satisfaction due to production in small farms in the Russian Federation in $2000-2017, \%$.

\begin{tabular}{|c|c|c|c|c|c|}
\hline Indicator & 2000 & 2005 & 2010 & 2015 & 2017 \\
\hline \multicolumn{6}{|c|}{ Potato } \\
\hline $\begin{array}{l}\text { The level of need satisfaction } \\
\text { due to production in small farms, } \\
\text { including }\end{array}$ & 95.0 & 96.0 & 71.5 & 97.7 & 108.4 \\
\hline - personal subsidiary farms & 93.7 & 93.0 & 67.0 & 87.9 & 97.7 \\
\hline - country farms & 1.3 & 3.0 & 4.4 & 9.8 & 10.7 \\
\hline \multicolumn{6}{|c|}{ Vegetables and gourds } \\
\hline $\begin{array}{l}\text { The level of need satisfaction } \\
\text { due to production in small farms, } \\
\text { including }\end{array}$ & 64.9 & 66.2 & 62.7 & 71.9 & 89.3 \\
\hline - personal subsidiary farms & 62.9 & 60.5 & 54.1 & 58.7 & 59.0 \\
\hline - country farms & 2.0 & 5.6 & 8.6 & 13.2 & 30.3 \\
\hline \multicolumn{6}{|c|}{ Meat and meat products } \\
\hline $\begin{array}{l}\text { The level of need satisfaction } \\
\text { due to production in small farms, } \\
\text { including }\end{array}$ & 38.5 & 34.2 & 28.3 & 23.0 & 21.6 \\
\hline - personal subsidiary farms & 37.3 & 32.7 & 26.2 & 20.4 & 18.9 \\
\hline - country farms & 1.2 & 1.5 & 2.1 & 2.6 & 2.7 \\
\hline \multicolumn{6}{|c|}{ Milk and dairy products } \\
\hline $\begin{array}{l}\text { The level of need satisfaction } \\
\text { due to production in small farms, } \\
\text { including }\end{array}$ & 46.5 & 45.8 & 44.3 & 42.2 & 41.8 \\
\hline - personal subsidiary farms & 44.9 & 43.2 & 40.5 & 36.9 & 35.4 \\
\hline - country farms & 1.6 & 2.6 & 3.8 & 5.3 & 6.4 \\
\hline \multicolumn{6}{|c|}{ Eggs } \\
\hline $\begin{array}{l}\text { The level of need satisfaction } \\
\text { due to production in small farms, } \\
\text { including }\end{array}$ & 28.5 & 26.0 & 22.6 & 21.2 & 19.8 \\
\hline - personal subsidiary farms & 28.1 & 25.3 & 21.8 & 20.4 & 18.8 \\
\hline - country farms & $\overline{0.4}$ & 0.7 & 0.7 & 0.9 & 1.0 \\
\hline
\end{tabular}

The opposite situation with the production of livestock products. Large agricultural enterprises are the main producers of livestock products. Agricultural holdings increase the scale of their activities. Personal farms lose their positions. The level of need satisfaction of all types of livestock production due to production in personal subsidiary farms is decreasing. 
However, country farms develop their activities. Their role has grown in food self-sufficiency in livestock products.

The conducted studies revealed a significant role of small farms in ensuring the prosperous security of Russia. Small farms have the potential to increase production volumes. This may lead to an increase in the level of food self-sufficiency of the state.

\section{Discussion}

The modern state of food security in Russia requires a revision of the state policy with respect to small farms. State policy should include strengthening financial support, developing mechanisms for the stable development of these forms. The volume of state support should be consistent with the socio-economic importance of agricultural producers.

The role of country farms annually increases in ensuring food security of Russia. In addition, farms are taxpayers (as opposed to personal subsidiary farms). Therefore, the priority areas of support for this form should be highlighted.

First, novice farmers need funding. The state provides grants for the organization of farms. However, the size of grants and the total amount of funding should be increased. The active use of these measures may lead to the creation of new farms, an increase in the employment of the rural population, and an increase in the production of agricultural products.

Secondly, the support of novice farmers contributes to the creation of new permanent jobs in rural areas. Comprehensive farmer support programs should take into account their contribution to increasing employment.

Thirdly, help is needed for personal subsidiary farms wishing to apply for the status of country farms. These farms are large, using large plots of land. Owners of personal subsidiary farms hire workers to produce agricultural products. Farm members sell large volumes of products on the market. This category of personal subsidiary farms transformed into peasant farms. Official registration of the new status is absent. This is due to the emergence of the tax burden in many ways. Therefore, there is a need to develop an algorithm for the transition of personal subsidiary farms to f country arms. Providing tax preferences is the best option. The level of tax preferences should be differentiated.

Fourth, infrastructure is not developed in rural areas. Logistic messages are in poor condition. The possibility of free product sales is absent due to this. Companies for storage and processing of products are not available in rural areas. Novice farmers are forced to sell unprocessed raw materials. The sale takes place in the autumn period. Prices for agricultural products are reduced at this time. Farmer support should be targeted. The size of subsidies should depend on the direction of infrastructure development. These measures will enable agricultural products to enter the federal and global markets.

Support for farmers is carried out in the framework of the State Program at present. Government support measures include:

- grant support to novice farmers;

- grant support for the development of family livestock farms;

- grant support for agricultural consumer cooperatives for the development of material and technical base;

- reimbursement of part of the interest rate on loans.

Grant support to farmers amounted to $10,298.6$ million rubles in 2017 . This is $21.2 \%$ more compared to 2013. The main volume of subsidies goes to support beginning farmers and developing livestock farms. The results are significant. Farms created 5,379 new permanent jobs. Farms increased agricultural production by 8.9 times. Cooperatives were able to create 774 permanent jobs. Farmers increased sales through cooperatives 17.5 times. 
Personal similar households are in a vulnerable position today. Most farms have small plots of land. The members of these farms sell small amounts of products. Many farms produce products only for their own consumption. However, the level of development of personal subsidiary farms is low. Personal farms are losing ground in ensuring Russia's food security. Personal farms did not increase the scale of activities to compensate for the values of personal subsidiary farms. The level of food security is reduced because of this.

Measures to support the production of agricultural products should be introduced. The state can provide subsidies for the released products. The support of the weak farm by the state authorities should be done by active participation in the development of complex projects of their financial improvement and modernization of production [8]. Personal farms cannot function autonomously. Their successful development requires the formation of ties with the subjects of the external environment - large agricultural enterprises, and country farms. This is possible through cooperative ties. Agricultural cooperation should include assistance in the supply, production, processing and marketing of products.

Personal subsidiary farms have problems with material and technical equipment. Specialized equipment is missing. The members of the farms cannot process the land plot with high quality. A similar problem occurs with the maintenance of animals. Comprehensive mechanization is absent in animal husbandry. This increases the complexity.

Personal subsidiary farms do not have sufficient financial resources. Farms do not have the ability to buy high-quality feed, highly productive breeding animals. Lack of access to appropriate markets, credit, education and locally appropriate agricultural research and extension can significantly impact family farmers [9].

Urbanization is a major problem. The rural population migrates to major cities. Outmigration, aversion to working in agriculture and the aging of farmers and farm managers are serious problems that raise questions about who will work in agriculture in the future [10]. This is due to housing, utilities, socio-economic conditions. Living conditions do not meet modern requirements. The state solves this problem in a complex. Government support measures are aimed at attracting young specialists to the countryside. Rural improvement programs are being implemented. This should provide an opportunity for the development of small farms in the countryside.

\section{Conclusions}

Ensuring food security is one of the main priorities of modern state policy in Russia. Government agencies are interested in the sustainable development of agricultural producers. Small farms play a huge role in food self-sufficiency and import substitution. The modern concept of development of agricultural production should take into account this fact. The strategic goal is to create conditions for the comprehensive development of small farms. The state support mechanism should include the following areas:

- carrying out institutional transformations: improvement of legislation, antimonopoly policy, personnel training, information and consulting support;

- development of rural infrastructure;

- increase in the volume of state support;

- the creation and development of cooperation between small forms of business and large enterprises.

The development of small farms is an integral part of the national agricultural policy. The results of the work of newly created farms, livestock farms showed that the development of small farms will allow to solve the key tasks in the field of import substitution in Russia.

\section{References}


1. R. Methorst, D. Roep, F. Verhees, J. Verstegen, NJAS - Wageningen Journal of Life Sciences, 81, 10 (2017) doi.org/10.1016/j.njas.2017.02.001

2. S. Lowder, J. Skoet, T. Raney, World Development, 87, 16-29 (2016) doi.org/10.1016/j.worlddev.2015.10.041

3. W. Morris, A. Henley, D. Dowell, Journal of Rural Studies, 53, 132-143 (2017) doi.org/10.1016/j.jrurstud.2017.05.014

4. E. Sapozhnikova, L. Domracheva, A. Timin, S. Grin, D. Loginov, Overcoming Uncertainty of Institutional Environment as a Tool of Global Crisis Management. Contributions to Economics, 21-30 (2017) doi.org/10.1007/978-3-319-60696-5_4

5. V. Glinskiya, L. Serga, M. Alekseev, N. Samotoya, E. Simonova, Procedia Manufacturing, 21, 838-845 (2018) doi.org/10.1016/j.promfg.2018.02.191

6. E. Karanina, E. Sapozhnikova, D. Loginov, A. Holkin, E. Sergievskaya, A. Zurakhovskii, MATEC Web of Conferences, $106 \quad$ (2017) doi.org/10.1051/matecconf/201710608079

7. F. Schierhorn, D. Müller, A. Prishchepov, M. Faramarzi, A. Balmann, Global Food Security, 3(3-4), 133-141 (2014) doi.org/10.1016/j.gfs.2014.10.007

8. G. Aigarinova, Z. Akshatayeva, M. Alimzhanova, Procedia - Social and Behavioral Sciences, 143, 884-891 (2014) doi.org/10.1016/j.sbspro.2014.07.511

9. B. Graeub, M. Chappell, H. Wittman, S. Ledermann, R. Kerr, B. Gemmill-Herrena, World Development, 87, 1-15 (2016) doi.org/10.1016/j.worlddev.2015.05.012

10. Z. Bednarikova, M. Bavorova, E.Ponkina, Journal of Rural Studies, 45, 99-111 (2016) doi.org/10.1016/j.jrurstud.2016.03.006 